\title{
Crimean Tatar Language
}

National Cancer Institute

\section{Source}

National Cancer Institute. Crimean Tatar Language. NCI Thesaurus. Code C153890.

A Kipchak Turkic language spoken mainly in Crimea, as well as small communities in the United States and Canada. 